\title{
Institutional Trust, Education, and Corruption: A Micro-Macro Interactive Approach
}

\section{Citation}

Hakhverdian, Armen, and Quinton Mayne. 2012. Institutional Trust, Education, and Corruption: A Micro-Macro Interactive Approach. Journal of Politics 74(3): 739-750.

\section{Published Version}

htttp://dx.doi.org/10.1017/S0022381612000412

\section{Permanent link}

http://nrs.harvard.edu/urn-3:HUL.InstRepos:9639965

\section{Terms of Use}

This article was downloaded from Harvard University's DASH repository, and is made available under the terms and conditions applicable to Open Access Policy Articles, as set forth at http:// nrs.harvard.edu/urn-3:HUL.InstRepos:dash.current.terms-of-use\#OAP

\section{Share Your Story}

The Harvard community has made this article openly available.

Please share how this access benefits you. Submit a story.

Accessibility 


\title{
Institutional Trust, Education, and Corruption: a Micro-Macro Interactive Approach
}

\author{
Armen Hakhverdian $^{*}$ and Quinton Mayne ${ }^{\dagger}$
}

(June 2012)

Forthcoming in Journal of Politics 73:3 (July 2012)

\footnotetext{
${ }^{*}$ Assistant Professor, Department of Political Science, University of Amsterdam.

${ }^{\dagger}$ Assistant Professor of Public Policy, Kennedy School of Government, Harvard University.
} 


\begin{abstract}
This paper examines how the effect of education on institutional trust varies crossnationally as a function of the pervasiveness of public-sector corruption. We approach institutional trust as a performance-based evaluation of political institutions. Given their greater capacity to accurately assess the level of corruption coupled with their stronger commitment to democratic values, we hypothesize that higher educated citizens should react differently to corruption from those with less education. Employing multilevel models we find that education has both a conditional and a conditioning effect on institutional trust. First, education is negatively related to institutional trust in corrupt societies and positively related to institutional trust in clean societies. Second, corruption's corrosive effect on institutional trust worsens as education improves. The paper ends with a discussion of the implications of these findings for the functioning of contemporary democracies.
\end{abstract}


Why are citizens in some countries more trusting of the actors and institutions of government than citizens in other countries? Over the past two decades this question has come to occupy an important place in the field of comparative political science (Dalton, 2004; Norris 1999a; Pharr and Putnam, 2000). In the large body of work that now exists on this question of political trust, a contradictory set of findings regarding the effect of education has gone largely unnoticed. Whereas some research shows that education boosts political trust (e.g., Anderson and Singer, 2008), in other work the effect of education is negative (e.g., Seligson, 2002); and in a third group of studies, education fails altogether to predict individual-level variation in political trust (e.g., Mishler and Rose, 2001). Interestingly, specialists of political behavior have puzzled over the same variability of the effect of education on electoral participation (Verba et al., 1978; Powell, 1986; Gallego, 2010). These authors show that this inconsistency of the effect of education on turnout is attributable to variation at the macro level. In a similar vein, we argue that the direction and magnitude of the effect of education on institutional trust depends on a country's political and institutional context. ${ }^{1}$

At the heart of our study lie the following two propositions. First, citizens grant and withhold trust based on their evaluation of the performance of the actors and institutions of government. Second, citizens with more education are not only more likely to be better able to identify practices that undermine the smooth functioning of democratic institutions, they are also more likely to be normatively troubled by such practices. Based on these twin claims, we hypothesize that political trust is determined by the interactive effect of a person's level of education on the one hand and the overall quality of their country's system of democratic governance on the other.

\footnotetext{
${ }^{1}$ An online appendix with supplementary material will be available after publication of the article at https://journals.cambridge.org/jop. The data used in this paper are accessible at http://ess.nsd.uib.no/ess/round4. Supporting materials necessary to reproduce the numerical results will be made available at www.quintonmayne.net upon publication.
} 
Using data from 21 European democracies, where system performance is operationalized using a measure of public-sector corruption, the results of our analyses strongly support a cross-level, interactive understanding of political trust. In countries with comparatively high levels of corruption, we find that education dampens political trust; in countries with low levels of corruption, education actually boosts political trust. Moreover, our study also demonstrates that the effect of corruption on political trust depends on educational attainment. Specifically, we find that citizens with the lowest levels of education are unresponsive to the effects of corruption; for all other citizens, the corrosive effects of corruption on political trust increase with education.

In contrast to existing work that examines the interactive effects of education on public opinion and political behavior, we go beyond a purely cognitive conception of education (Huber et al., 2005; Krause, 1997; Jacoby, 1991; Nagler, 1991). We posit that education not only facilitates the acquisition and processing of information, it also fundamentally informs how citizens react to certain types of information. Thus, a key innovation of this study is that in specifying our hypotheses we are sensitive as much to the normative as to the knowledgeenhancing properties and effects of education. This theoretical refinement challenges the common proposition that rising levels of education have been responsible for declines in a variety of forms of political support observed in many advanced industrial democracies over the past half century (Dalton, 2004, pp. 86-91; Inglehart, 1999, pp. 245-256). What we show is that there is nothing about education per se that should encourage institutional distrust. Ultimately the role played by the improving educational profile of contemporary societies is to bring into striking and at times alarming relief the overall democratic quality of a country's processes of government.

In the next section we discuss the concept of institutional trust as an evaluative, performance-based orientation toward political actors and institutions. We then elaborate the accuracy- and norm-inducing role played by education in this process of evaluation, which 
results in citizens granting or withholding political trust depending on the quality of their country's system of governance. The following section describes the data and methods that we use to estimate this micro-macro interactive model of political trust. After presenting the results of this model, we discuss the importance and implications of our findings both for the study of political trust and for the functioning of democracy more generally.

\section{Theory}

\section{Institutional Trust}

In the course of their lives citizens are vulnerable to the decisions and actions of a myriad of political actors and institutions. Political trust refers to the faith that citizens place in political actors and institutions not to act in ways that will do them harm (Levi and Stoker, 2000;

Newton, 1999). Objects of political trust can range from the abstract to the very specific (Norris, 1999b). Forming a mid-range object of trust are political institutions, examples of which include local government, the civil service, the legal system, parties, parliament, the police, judges, and politicians. Lying at the very heart of contemporary democratic life and following a long line of research from comparative political behavior, we focus on public trust in this category of political institutions and actors.

Over the years a number of compelling arguments and empirical findings have been put forward in support of the study of institutional trust. Most fundamentally, institutional trust has commonly been conceived of as a democratic good in and of itself as well as an important gauge of a democracy's political health (Dalton, 2004; Pharr and Putnam, 2000). A number of studies have also argued that a public's trust in the actors and institutions of political authority facilitates democratic consolidation in that institutionally-trusting individuals have been found to be more supportive of democratic principles (Seligson and Carrión, 2002). In addition, existing research underscores the importance of institutional distrust as a determinant of political participation, especially non-electoral participation such as protest activity and 
political consumerism (Mishler and Rose, 2005; Micheletti et al., 2003). More recent research has also shown how institutional trust is related to a range of key political and non-political attitudes, including public policy preferences (Chanley et al., 2000; Hetherington, 2005) and trust in fellow citizens (Zmerli and Newton, 2008). Finally, several studies have drawn attention to the positive relationship between institutional trust and compliance with government regulation and civic duty (Letki, 2006; Tyler, 1990).

Building on existing theoretical and empirical research from the field of comparative political behavior, we understand institutional trust within a "rationalist" framework as a primarily evaluative orientation (Hetherington, 1998; Mishler and Rose, 2001). Thus, in contrast to "culturalist" understandings of institutional (dis)trust as deeply socio-culturally embedded, we view institutional trust as a product of individual-level judgment regarding the performance of political institutions and actors. Borrowing the conceptual approach developed with regard to the European Union by Fritz Scharpf (1999), we propose that citizens evaluate political institutions and actors based on two different sets of performance criteria: those related to "input" or procedural performance and those related to "output" or policy performance.

Procedural performance is synonymous with the long-standing democratic adage of government by the people. Citizens judge procedural performance according to the extent to which the democratic promise of political fairness and equality is made real by the rules, procedures, norms, and structures that guide and constrain the functioning of political institutions and the behavior of political actors. Policy performance, on the other hand, is synonymous with the notion of government for the people. As such, citizens evaluate policy performance based on substantive considerations concerning how successful political institutions and actors are in implementing policies and providing services that are responsive to the public's preferences and priorities. Where political actors and institutions achieve high levels of procedural and policy performance, we anticipate citizens will reward such positive 
performance with trust. In contrast, we expect citizens to express low levels of institutional trust where the actors and institutions of democratic political authority perform poorly procedurally and in terms of policy responsiveness.

This idea that institutional trust is fundamentally the product of a performance-based evaluation finds a great deal of support in the sizeable body of work that has examined the effects of public-sector corruption on attitudes related to political support. Time and again we see the corrosive effects of corruption on people's trust in the actors and institutions of government (Anderson and Tverdova, 2003; Chang and Chu, 2006; Mishler and Rose, 2001; Seligson, 2002). What this literature highlights is that corruption undermines political trust in a number of different ways. On the one hand, it affects the procedural performance of political institutions; on the other hand, corruption makes it extremely difficult for governments to produce policies and services that are responsive to the general public (Rothstein and Uslaner, 2005; Warren, 2004).

\section{Accuracy- and norm-inducing functions of education}

In defining the concept of institutional trust and describing the process of performance evaluation behind it, we have painted an undifferentiated picture of citizens. When it comes to the process of performance evaluation undergirding institutional trust, there are sound theoretical and empirical reasons to think about citizens in heterogeneous rather than homogeneous terms (Anderson and Singer, 2008). Specifically, we propose that citizens will assess and react to the general performance of their respective country's political institutions differently depending on their level of education. This idea that education plays a pivotal role is based on an abundance of evidence identifying the deep imprint left by education both on citizens' capacity to acquire and process information and on the types of values and principles 
citizens hold dear. For simplicity's sake, we will refer to these as the accuracy-inducing and norm-inducing functions of education. ${ }^{2}$

Any act of evaluation requires a capacity to acquire and process information related to the object being evaluated. For the present purposes the object of evaluation is the performance of political institutions. Single-country and comparative research has demonstrated that, even after controlling for a host of other variables, formal education produces a number of different and oftentimes related changes in individuals that facilitate the acquisition and processing of information necessary for arriving at an accurate assessment of the functioning of political institutions. For one, education has repeatedly been shown to have a positive effect on the amount and type of attention citizens pay to politics and public affairs. For example, the more educated consistently express more interest in politics than the less educated (Delli Carpini and Keeter, 1996; Verba et al., 1995). Education has been shown to be positively related to time spent reading newspapers, itself an important means of obtaining political information (Dee, 2004; Elvestad and Blekesaune, 2008; Shehata and Strömbäck, 2011). Moreover, citizens with higher levels of education have a greater tendency to undertake a range of political activities that provide opportunities for learning about the quality of political institutions. This includes, for instance, attending public meetings, making contact with public officials, and following electoral campaigns (Aars and Strømsnes, 2007; Milligan et al., 2004; Pattie et al., 2004).

A large body of research also underscores the important direct and indirect role played by formal education in enhancing political knowledge. The more educated are more likely to respond correctly to questions of fact related to the key players and workings of their political system (Hyman et al., 1975; Delli Carpini and Keeter, 1996; Milner 2002). The more educated have also been shown to be better able to place parties on issues and ideology and more likely to form attitudes consistent with their own ideological leanings (Aarts and Semetko, 2003; Gordon and Segura, 1997; Jacoby, 1991). Interestingly, there is also evidence

\footnotetext{
${ }^{2}$ We thank one of our anonymous reviewers for suggesting this phrasing.
} 
to suggest that, compared to the less educated, the higher educated are more likely to accurately assess their particular country's overall respect for human rights (Anderson et al., 2005).

While education makes it easier for citizens to acquire and process information related to the quality of the workings of democratic institutions, there is nothing intrinsic about the possession of such information that should lead citizens to view underperforming or mismanaged institutions negatively. In order to hypothesize about this link between knowledge and evaluation we need to establish how citizens react to information about phenomena, such as corruption, that undermine democratic performance. Education has long been shown to leave an indelible mark both on people's broad normative proclivities and on the store they set by democratic rule. For example, over the years research has repeatedly shown that support for a range of liberal moral values, including equality and tolerance, grows with years of schooling (Bobo and Licari, 1989; Hyman and Wright, 1979; Nie et al., 1996; Vogt, 1997). Scholars have also argued that in established democracies the more educated are more likely to support and defend core democratic values and principles (Dalton, 1994, p. 483; Hibbing and Theiss-Morse, 2002, p.771; McClosky and Zaller, 1984, pp. 239-240). In the past decade, drawing in part on earlier waves of modernization research, a body of work has emerged that also highlights the positive links between years of schooling and support for democracy in new democracies and non-democracies (Evans and Rose, 2007; Jamal, 2006; Kotzian, 2011). Thus, in addition to being better able to accurately identify practices that undermine the smooth functioning of democratic institutions, these different strands of research suggest that the better educated will also be normatively troubled by such practices.

As discussed earlier, corruption represents a major challenge to the performance of political institutions. As such, and in view of the accuracy- and norm-inducing functions of education, when faced with the absence or presence of corruption we expect citizens to grant and withhold institutional trust differently depending on their level of education. In other words, 
we hypothesize that corruption and education interact to affect a person's level of trust in political institutions. In hypothesizing that such an interactive effect exists we are making two separate, symmetric claims (see Berry et al., 2007): one is about the conditional effect of education; the other is about the conditioning effect of education.

Hypothesis 1: Regarding the conditional effect of education, we hypothesize that in countries with comparatively high levels of corruption more educated citizens will react more negatively to corruption than the less educated. In contrast, in comparatively clean countries we hypothesize that more educated citizens will react more positively to the absence of corruption than the less educated.

Hypothesis 2: As for the conditioning effect of education on corruption, we envisage that while corruption will corrode institutional trust among all citizens irrespective of their level of education, the size of this negative effect of corruption on institutional trust should increase with a person's level of education.

In testing the first hypothesis we are able to address a long-standing but overlooked aspect of existing research that becomes clear from surveying important single-country and comparative studies regarding the effects of education on political trust. We can classify existing studies according to whether they examine individual-level variations in political trust in one or more advanced industrial democracy, in one or more of the new and/or low-, middle-, and high-income democracies of Central and Eastern Europe, Latin America, Africa, and Asia, or in a mix of old and new, low-, middle-, and high-income democracies (see Table A1 in the online appendix). Of the existing research that is based on data from the world's longeststanding, advanced industrial democracies, many studies show a positive effect of education (e.g., Anderson et al., 2005; Rohrschneider and Schmitt-Beck, 2002), whereas only one study 
shows education as having a negative effect on political trust (Cooke and Gronke, 2005). In contrast, many studies show education as negatively related to political trust in the world's newer and less affluent democracies (e.g., Chang and Chu, 2006; Canache and Allison, 2005). Moreover, equally telling is the fact that the effect of education on political trust fails to achieve statistical significance in a number of pieces of research using data from both old and new democracies (e.g., Anderson and Tverdova, 2003). These contradictory findings suggest that that the effect of education on institutional trust is context specific. The empirical analyses that follow demonstrate that this is indeed the case.

\section{Data and variables}

In order to test whether institutional trust is a function of the interaction of educational achievement and corruption, we make use of Round 4 of the European Social Survey (ESS) conducted in 2008-2009. The necessary individual- and macro-level variables were available for eight Eastern and Central European and 13 Western European democracies: namely, Belgium, Croatia, the Czech Republic, Denmark, Estonia, Finland, France, Germany, Great Britain, Greece, Hungary, Latvia, the Netherlands, Norway, Poland, Portugal, Romania, Slovenia, Spain, Sweden, and Switzerland. This section outlines the key variables and data sources of our study. The exact wording of the survey items can be found in the online appendix.

\section{Dependent variable}

Institutional trust constitutes the dependent variable of this study. The ESS asks respondents about their levels of trust in their country's parliament, legal system, police, politicians, political parties, the European Parliament, and the United Nations. Since our substantive focus is on domestic institutions and their respective performance we chose to drop trust in international organizations such as the European Parliament and the United Nations from our 
index. We combine the remaining five items to create an index of institutional trust. ${ }^{3}$ For our sample of 21 European democracies, Cronbach's alpha, a widespread measure of reliability for scales, ranges from 0.83 in Poland to 0.92 in Romania. These figures are well above the conventional boundaries for scale construction, so for our dependent variable we simply calculate the mean score of these five separate domestic trust items. ${ }^{4}$

Institutional trust has a theoretical range of 0 ('no trust at all') to 10 ('completely trusting'). The empirical, aggregate-level range runs from 2.78 in Latvia to 6.58 in Denmark (see Figure A1 in the online appendix). We can divide the sample into roughly three sets of countries based on levels of institutional trust. The first group of 'highly trusting' countries consists of Sweden, the Netherlands, Switzerland, Norway, Finland, and Denmark. A second group of 'moderately trusting' countries consists of Slovenia, Estonia, Spain, France, Great Britain, Belgium, and Germany. Finally, a third group of 'low trusting' countries consists of Latvia, Hungary, Croatia, Poland, the Czech Republic, Portugal, Romania, and Greece. As this grouping makes clear, Central and Eastern European countries generally exhibit lower levels of trust than their Western European counterparts (also see Mishler and Rose, 1997). However, while controlling for region is therefore important, there are noticeable exceptions to this pattern. Portugal and Greece, for instance, are on average less trusting than Slovenia and Estonia. Furthermore, there are stark within-region differences in institutional trust, so even after controlling for region sizeable variation in trust remains among the Western European and Central and Eastern European countries in our sample.

\footnotetext{
${ }^{3}$ Klingemann (1999) and Anderson and Singer (2008) adopt a similar empirical strategy in their studies of political trust.

${ }^{4}$ An index consisting of all seven trust items is virtually identical to the five-item index (Pearson's $r=0.96$ ), and employing it as the dependent variable does not alter any of the substantive results reported here.
} 


\section{Independent variables}

The two main independent variables are level of education and corruption. For the former, we recoded the original ESS education item into four categories. The lowest education category contains those respondents with no qualification or only primary education $(16.0 \%$ of the entire sample). The next category contains those with a lower secondary level of education (19.4\%). The third category consists of individuals with an upper-secondary or post-secondary, (non-university) education (40.9\%). Finally, the highest category contains those with a university education $(23.7 \%){ }^{5}$

The primary macro-level, contextual variable of interest is corruption. We draw upon Transparency International's well-known Corruption Perception Index (CPI) which gauges the perceived level of public-sector corruption. The CPI is a composite measure, consisting of 13 items from 11 independent institutions, that taps perceptions of corruption among country experts and business leaders and has been employed in numerous other comparative studies of the causes and consequences of corruption (Treisman, 2000; Anderson and Tverdova, 2003; Gerring and Thacker, 2004). ${ }^{6}$ Higher scores on the CPI indicate a relative lack of corruption in the public sector and political sphere. Using data for 2008, the CPI ranges from 9.3 in Denmark and Sweden to 3.8 in Romania. The fact that the CPI is a measure of perceived corruption could raise questions of endogeneity, but Anderson and Tverdova (2003) employ a Hausman test to show that corruption is not endogenous to system support. We therefore include the CPI as an explanatory variable with the knowledge that the CPI is exogenous to mass attitudes towards the political system.

\footnotetext{
${ }^{5}$ We also conduct the analysis using the original seven-category education item from the ESS to check whether our results are sensitive to configurations of the education categories. The findings turn out to be similar.

${ }^{6}$ For a detailed description of the construction of the Corruption Perception Index, see http://www.transparency.org/policy research/surveys indices/cpi/2008.
} 


\section{Control variables}

Previous comparative studies have identified a host of individual-level factors besides level of education that predict political trust (Mishler and Rose, 2001; Chang and Chu, 2006; Anderson and Singer, 2008; Van Der Meer, 2010). These include demographic and socio-economic variables such as age, gender, income, religious denomination, and religious attendance. We also control for pre-adult experiences and influences by including paternal level of education (see Kam and Palmer, 2008). Furthermore, we control for several attitudinal and behavioral variables that have been shown to be positively related to political trust, including social trust (Zmerli and Newton, 2008), election winner or loser status (Anderson and Tverdova, 2003), and satisfaction with the present state of the national economy (Mishler and Rose, 2001; Rohrschneider and Schmitt-Beck, 2002). ${ }^{7}$

At the country level, the control variables include level of development as captured by GDP per capita, level of unemployment, and a region dummy for Central and Eastern Europe (Anderson and Singer, 2008). Some scholars have made the argument that the inclusion of citizens into the political process induces more positive attitudes toward the political system (Lijphart, 1999). We therefore add the disproportionality of the electoral system, as calculated by Gallagher's least squares index (Gallagher, 1991), to our country-level controls. We refrain from including additional country-level controls due to our relatively small sample of countries.

\section{Method}

A study of the link between macro-politics and micro-behavior calls for data collection at the level of individuals as well as countries. Since individuals are nested within national contexts an explicitly multilevel modeling strategy is in order (Snijders and Bosker, 1999).

\footnotetext{
${ }^{7}$ We note that some of these control variables might be endogenous to our dependent variable. For example, Hetherington (1998) shows that political trust is an important cause of perceptions of presidential performance.
} 
Steenbergen and Jones (2002) recommend, as a first step toward building appropriate multilevel models, checking whether and to what extent the dependent variable in question varies across the relevant levels of analysis. Applied to our case, we should investigate whether institutional trust varies between individual respondents as well as between countries. Figure 1 has already underlined the large between-country differences in institutional trust. What therefore remains to be investigated is the extent to which this variation can be accounted for by the characteristics of citizens in these specific countries or by macro-level characteristics specific to the countries themselves.

Following the advice of Steenbergen and Jones (2002), we decompose the variance in institutional trust into individual-level variance and country-level variance such that

$$
\text { Institutional trust } t_{i j}=\gamma_{00}+v_{0 j}+\varepsilon_{i j}
$$

Here, institutional trust varies around a grand mean $\gamma_{00}$, while $v_{0 j}$ and $\varepsilon_{i j}$ capture deviations from the grand mean for country $j$ and individual $i$ respectively. Since both variance components are statistically significant (see Table A2 in the online appendix), we can conclude that there appears to be significant variance in institutional trust at both levels providing statistical justification for adopting a multilevel approach. In addition, about 27 percent of the total variance in institutional trust occurs at the country-level, so by ignoring contextual variance one is likely to miss out on important explanations of institutional trust.

We now specify a random-coefficient model that assesses the interactive effect of education and corruption on institutional trust, while controlling for confounding factors at both the individual and country levels. At the individual level education takes the form of three dummy variables with the lowest education cohort functioning as the reference category. The model contains a variance component for the intercept, accounting for mean differences in institutional trust across countries, and for the education dummies, effectively allowing the 
impact of education on political trust to vary across the 21 sampled democracies. The variance estimates of the slopes are all statistically significant and increase in magnitude as education level increases. The fact that education has a varying impact on institutional trust is of course the focus of this study. A cross-level interaction between corruption and the education categories then estimates the extent to which, on the one hand, the effect of education on institutional trust is contingent upon corruption, and on the other, the effect of corruption on institutional trust is contingent upon a person's education. ${ }^{8}$ The original intra-class correlation drops from 0.27 in the empty model to 0.17 when we allow the slopes to vary across countries and add individual-level controls. This figure drops even further to 0.03 after introducing the country-level controls and the cross-level interactions, which underscores the importance of modeling institutional trust hierarchically.

\section{Empirical Findings}

As a preliminary test of our hypotheses, we plot mean levels of institutional trust among the highest and lowest educated in each of the 21 democracies in our sample. Figure 1 displays these mean levels, with countries ranked according to their CPI score. First, congruent with Hypothesis 1, the highest educated exhibit more political trust than the lowest educated, but only when corruption is low. Figure 1 shows that education boosts political trust in the countries towards the right-hand side of the graph. The difference in trust between the highest and lowest educated disappears as corruption increases and even reverses toward the left-hand side of the graph. In Romania, Croatia, Greece, and Latvia the least educated display higher levels of institutional trust than the most educated. This graphical analysis lends tentative support to the hypothesis that the effect of education on institutional trust is not uniform across countries but rather depends on the context in which citizens are nested. Second, in line with

\footnotetext{
${ }^{8}$ Our dependent variable is normally distributed, so we use Maximum Likelihood to estimate a linear multilevel regression. All analyses were conducted using STATA 11.
} 
Hypothesis 2, institutional trust decreases as corruption rises both among the highest and lowest educated groups, but the decline is greatest among the highest educated. Of course, as Figure 1 displays net effects of education on political trust, it remains to be seen whether these findings will be reproduced in a fully-specified hierarchical model. To this we turn next.

\section{INSERT FIGURE 1}

Table 1 presents the estimation results from our random coefficients model. Before moving on to our main findings, however, we note that institutional trust is positively related to paternal education, income, religious attendance, and belonging to a religion, and negatively related to age and being male. In addition, several indicators of civic and political engagement have a positive effect on institutional trust. People who are more trusting of other people are also more likely to exhibit institutional trust compared to less socially trusting individuals (Zmerli and Newton, 2008). Moreover, those who evaluate the state of the economy more positively will generally be more trusting of political institutions (Mishler and Rose, 2001). Finally, nonvoters and those having cast their votes for opposition parties display lower levels of institutional trust than election winners (Anderson and Tverdova, 2003). As for the countrylevel controls, most of these fail to reach conventional standards of statistical significance. We do note, however, that citizens of Central and Eastern European countries report lower levels of institutional trust than those of Western European countries even after controlling for corruption and macro-economic performance.

\section{INSERT TABLE 1}

Under which conditions can we expect a positive or negative impact of education on institutional trust? The results of Table 1 show that education is negatively related to 
institutional trust when the Corruption Perception Index is zero. Thus in the hypothetical case of a perfectly corrupt society the most educated are less politically trusting than the least educated (1.59 points less trusting to be exact). The interaction terms reveal that this gap decreases as the CPI increases. In a perfectly clean society $(\mathrm{CPI}=10)$, the highest educated are estimated to be more trusting of political institutions than the lowest educated by 0.83 points. Of course, CPI values of 0 and 10 do not really exist. In the real-world settings of our sample of countries, the CPI runs from 3.8 in Romania to 9.3 in Denmark and Sweden. Using the estimates from our model, Figure 2 charts the marginal effect of education on institutional trust for different values of the CPI. ${ }^{9}$ Education is negatively related to institutional trust for countries whose CPI is lower than 6.1 (which includes the Czech Republic, Croatia, Greece, Hungary, Latvia, Poland, Portugal, and Romania). The effect of education on institutional trust is non-significant if the CPI lies above 6.1 and below 7.0 (a range that covers Estonia, France, Slovenia, and Spain). Finally, education has a positive effect on institutional trust for countries whose CPI exceeds 7.0 (encompassing Belgium, Denmark, Finland, Germany, Great Britain, the Netherlands, Norway, Sweden, and Switzerland).

\section{INSERT FIGURE 2}

In line with Hypothesis 1, in relatively corrupt societies the most educated are more distrustful than the least educated, in moderately clean societies they are equally trusting as the least educated, and in relatively clean societies they are more trusting. By explicitly modeling the possibility that corruption and education interact, we are able to isolate the conditions under which education has a positive, non-significant, and negative effect on institutional trust and, in so doing, we are able to resolve the inconsistency of the effects of education as reported in previous research (see Table A1 in the online appendix).

\footnotetext{
${ }^{9}$ We made use of the STATA syntax that accompanies Brambor et al., 2006.
} 
Next, we deal with the conditioning effect of education as formulated in Hypothesis 2. The coefficient for corruption in Table 1 captures the effect of corruption on institutional trust for the group with the lowest level of educational attainment. These are respondents who have not completed primary education or who have obtained a qualification at the primary or first stage of basic education. Corruption does not seem to affect the institutional trust of the least educated cohorts, controlling for a host of relevant individual-level and country-level characteristics. While the coefficient has the expected sign - the higher the Corruption Perception Index, the higher institutional trust - it fails to reach accepted levels of statistical significance. However, corruption has a statistically significant effect on the institutional trust of all other education groups. This leads us to conclude that corruption has a corrosive impact on trust in political institutions for all but the lowest-education cohorts, and that this corrosive effect increases as citizens attain higher levels of education.

\section{INSERT FIGURE 3}

Figure 3 summarizes our statistical analyses by calculating the predicted levels of institutional trust across education groups and levels of corruption. By keeping all other variables in Model 1 at their mean or mode we can determine the effect of education alone on institutional trust at various values of the Corruption Perception Index. It is clear from this figure that the most educated trust or distrust political institutions based on the overall performance of their political system. Institutional trust among the most educated covaries strongly alongside the Corruption Perception Index. The difference in institutional trust between two highly educated individuals, one from Sweden and the other from Romania, is approximately 2.0 points on a 0 10 scale. By contrast, the same difference is approximately less than half a point for the least educated. Given that the results reported in Table 1 indicate that this difference is not 
statistically significant at the .05 level, we cannot reliably infer that corruption affects institutional trust among citizens with the lowest levels of education.

\section{Conclusion}

This study examines the context-specific effects of education on institutional trust. The theory that we test was developed around the following two propositions. First, citizens grant or withhold trust as a way of evaluating political institutions for their performance. Second, citizens with more education are not only more likely to be better able to identify practices that undermine the smooth functioning of democratic institutions, they are also more likely to be normatively troubled by such practices. In line with our expectations we find that the direction and magnitude of the effect of education is conditional upon the pervasiveness of public-sector corruption: in countries with low levels of corruption education boosts institutional trust; in countries with comparatively high levels of corruption education dampens institutional trust. In addition, our analyses largely support our hypothesis that education also moderates the effect of corruption on institutional trust. Specifically, we find that the corrosive effect of corruption on political trust worsens as education improves (except for the least educated whose trust in political institutions we find is unaffected by corruption).

The results of our analyses have implications not just for future comparative research on the causes of public opinion and the attitudinal effects of political corruption but also for better understanding the functioning of democracy. In the literature that has emerged on corruption over the past twenty years one of the clearest and most consistent findings is that corruption undermines people's trust and confidence in the actors and institutions of democratic government. Thus far, almost all of this research has focused on the direct effects of corruption on political support. In line however with a few other existing pieces (Anderson and Tverdova, 2003; Herreros and Criado, 2007), our study underscores the importance of developing and testing theories that elucidate the conditional nature of the attitudinal (as well 
as the behavioral) consequences of corruption. Moreover, our finding that corruption fails to impact the institutional trust of the least educated points to the need for additional scholarship on the micro- and/or macro-conditions under which corruption and other forms of systemic dysfunctionality become, worryingly from a democratic point of view, politically irrelevant for specific groups of citizens.

Despite a long tradition of work emphasizing the links between educational achievement and democratic commitment, scholars of political behavior exploring the interactive effects of education have to date focused their attention on the knowledge-enhancing, accuracy-inducing functions of education. A key contribution of the present study is that it incorporates the normative dimensions of education when theorizing about the conditional and conditioning effects of education on public opinion. In elaborating our hypotheses in a way that is sensitive to both the cognitive and the moral properties of education, the results of our analyses strongly support a "rationalist" understanding of institutional trust. Citizens with comparable levels of education systematically express different levels of political trust depending on the overall performance of their particular country's political system. This clearly suggests that rather than being something fixed and deeply culturally embedded trust is generated through a process that is fundamentally evaluative in nature. As such, our findings warn against viewing societies that express high levels of institutional trust in the aggregate as either politically docile or lacking the skepticism necessary for democratic maturity, or indeed assuming that countries with low aggregate levels of political trust are doomed in perpetuity.

Finally, the findings of our analyses point to some important potential political consequences arising from the changing educational profile of many of today's middle- and high-income democracies. In recent decades, and as a response to the demands and insecurities arising from economic globalization, governments across the world have increasingly been pursuing policies aimed at promoting a knowledge-based economic model. A key component of these policies has been to invest heavily in raising educational standards. 
For example, across OECD member countries completion rates of undergraduate degree programs rose by 21 percentage points between 1995 and 2008 (OECD, 2010, p. 61). Such rapidly increasing aggregate levels of education have particularly challenging consequences where levels of corruption are high. As several of the countries in our sample attest, rooting out corruption can prove very difficult. After two decades of democratic rule corruption remains relatively high in a number of Central and Eastern European countries; the same is equally true of Greece, for example, which has enjoyed democracy for even longer. Given this contrast between, on the one hand, the speed with which educational standards are rising across the democracies from which our sample of countries is drawn and, on the other hand, the slow pace at which political authorities are able or willing to stamp out corrupt practices, our findings suggest that the problem of low-level institutional trust in contexts of high corruption is likely only to worsen in the medium term. In and of itself this potential development is normatively troubling. In addition however, as noted earlier existing comparative research shows that persistently low levels of institutional trust can have serious ramifications for state-society relations in these democracies. Possible effects include increasing levels of protest, political apathy and disengagement from formal, electoral politics, an upturn in voting for anti-system parties, diminishing support for redistributive government action aimed at tackling socio-economic inequalities, and higher levels of non-compliance with government regulations. 


\section{Acknowledgments}

Both authors contributed equally to this work. We thank Imke Harbers, Sara Binzer Hobolt, Amaney Jamal, Jonas Pontusson, Jan Teorell, Tom Van Der Meer, the anonymous reviewers, and the editors for their valuable feedback on earlier versions. Any errors remain our responsibility. 


\section{References}

Aars, Jacob, and Kristin Strømsnes. 2007. "Contacting as a Channel of Political Involvement: Collectively Motivated Individually Enacted." West European Politics 30(1): 93-120.

Aarts, Kees, and Holli A. Semetko. 2003. “The Divided Electorate: Media Use and Political Involvement." Journal of Politics 65(3): 759-784.

Anderson, Christopher J., and Matthew M. Singer. 2008. "The Sensitive Left and the Impervious Right: Multilevel Models and the Politics of Inequality, Ideology, and Legitimacy in Europe." Comparative Political Studies 41(4/5): 564-599.

Anderson, Christopher J., and Yuliya V. Tverdova. 2003. "Corruption, Political Allegiances, and Attitudes Toward Government in Contemporary Democracies." American Journal of Political Science 47(1): 91-109.

Anderson, Christopher J., André Blais, Shaun Bowler, Todd Donovan, et al. 2005. Losers' Consent: Elections and Democratic Legitimacy. Oxford; New York: Oxford University Press.

Berry, William D., Justin Esarey, and Jacqueline H. Rubin. 2007. “Testing for Interaction in Binary Logit and Probit Models: Is a Product Term Essential?” Working Paper.

Bobo, Lawrence, and Frederick C. Licari. 1989. "Education and Political Tolerance: Testing the Effects of Cognitive Sophistication and Target Group Affect.” Public Opinion Quarterly 53(3): 285-308.

Brambor, Thomas, William Roberts Clark, and Matt Golder. 2006. "Understanding Interaction Models: Improving Empirical Analyses.” Political Analysis 14(1): 63-82.

Canache, Damarys, and Michael E. Allison. 2005. "Perceptions of political corruption in Latin American democracies." Latin American Politics and Society 47(3): 91-111. 
Catterberg, Gabriela, and Alejandro Moreno. 2006. "The Individual Bases of Political Trust: Trends in New and Established Democracies." International Journal of Public Opinion Research 18(1): 31-48.

Chang, Eric C. C., and Yun-han Chu. 2006. "Corruption and Trust: Exceptionalism in Asian Democracies?" Journal of Politics 68(2): 259-271.

Chanley, Virginia A., Thomas J. Rudolph, and Wendy M. Rahn. 2000. “The Origins and Consequences of Public Trust in Government." Public Opinion Quarterly 64(3): 239256.

Cook, Timothy E., and Paul Gronke. 2005. "The Skeptical American: Revisiting the Meanings of Trust in Government and Confidence in Institutions." Journal of Politics 67(3): 784803.

Dalton, Russell J. 1994. "Communists and Democrats: Democratic Attitudes in the Two Germanies.” British Journal of Political Science 24(4): 469-493.

2004. Democratic Challenges, Democratic Choices: The Erosion of Political Support in Advanced Industrial Democracies. Oxford; New York: Oxford University Press.

Dee, Thomas S. 2004. “Are there civic returns to education?” Journal of Public Economics 88(9-10): 1697-1720.

Delli Carpini, Michael X., and Scott Keeter. 1996. What Americans Know about Politics and Why It Matters. New Haven, CT.: Yale University Press.

Elvestad, Eiri, and Arild Blekesaune. 2008. "Newspaper Readers in Europe.” European Journal of Communication 23(4): 425-447.

ESS Round 4: European Social Survey Round 4 Data (2008). Data file edition 4.0. Norwegian Social Science Data Services, Norway - Data Archive and distributor of ESS data. 
Evans, Geoffrey, and Pauline Rose. 2007. "Support for Democracy in Malawi: Does Schooling Matter?" World Development 35(5): 904-919.

Gallagher, Michael. 1991. "Proportionality, disproportionality and electoral systems." Electoral Studies 10(1): 33-51.

Gallego, Aina. 2010. "Understanding unequal turnout: Education and voting in comparative perspective." Electoral Studies 29(2): 239-248.

Gerring, John, and Strom C. Thacker. 2004. "Political Institutions and Corruption: The Role of Unitarism and Parliamentarism.” British Journal of Political Science 34(2): 295-330.

Gordon, Stacy B., and Gary M. Segura. 1997. "Cross-national variation in the political sophistication of individuals: Capability or choice?" Journal of Politics 59(1): 126-147.

Herreros, Francisco, and Henar Criado. 2007. "Political support taking into account the institutional context." Comparative Political Studies 40(12): 1511-1532.

Hetherington, Marc J. 1998. “The Political Relevance of Political Trust.” American Political Science Review 92(4): 791-808.

2005. Why trust matters: declining political trust and the demise of American Liberalism. Princeton, N.J.: Princeton University Press.

Hibbing, John R., and Elizabeth Theiss-Morse. 1995. Congress as Public Enemy: Public Attitudes toward American Political Institutions. New York: Cambridge University Press.

2002. Stealth Democracy: Americans'Beliefs about How Government Should Work. Cambridge, UK; New York: Cambridge University Press. 
Huber, John D., Georgia Kernell, and Eduardo L. Leoni. 2005. "Institutional Context, Cognitive Resources and Party Attachments Across Democracies.” Political Analysis 13(4): 365-386.

Hyman, Herbert Hiram, and Charles Robert Wright. 1979. Education's Lasting Influence on Values. Chicago: Chicago University Press.

Hyman, Herbert Hiram, Charles Robert Wright, and John Shelton Reed. 1975. The Enduring Effects of Education. Chicago: Chicago University Press.

Inglehart, Ronald. 1999. "Postmodernization Erodes Respect for Authority, but Increases Support for Democracy.” In Critical Citizens: Global Support for Democratic Government, ed. Pippa Norris. Oxford; New York: Oxford University Press, 236-256.

Jacoby, Wade G. 1991. "Ideological identification and issue attitudes.” American Journal of Political Science 35(1): 178-205.

Jamal, Amaney A. 2006. "Reassessing Support for Islam and Democracy in the Arab World?" World Affairs 169(2): 51-63.

Kam, Cindy D., and Carl L. Palmer. 2008. "Reconsidering the Effects of Education on Political Participation.” Journal of Politics 70(3): 612-631.

Klingemann, Hans-Dieter. 1999. "Mapping Political Support in the 1990s: A Global Analysis.” In Critical Citizens: Global Support for Democratic Government, ed. Pippa Norris. Oxford; New York: Oxford University Press, 31-56.

Kotzian, Peter. 2011. "Public support for liberal democracy." International Political Science Review 32(1): 23 -41. 
Krause, George A. 1997. "Voters, Information Heterogeneity, and the Dynamics of Aggregate Economic Expectations.” American Journal of Political Science 41(4): 1170-1200.

Letki, Natalia. 2006. "Investigating the Roots of Civic Morality: Trust, Social Capital, and Institutional Performance.” Political Behavior 28(4): 305-325.

Levi, Margaret, and Laura Stoker. 2000. "Political Trust and Trustworthiness." Annual Review of Political Science 3(1): 475-507.

1999. Patterns of Democracy: Government Forms and Performance in Thirty-six

Countries. New Haven: Yale University Press.

McClosky, Herbert, and John R. Zaller. 1984. The American Ethos: Public Attitudes Toward Capitalism and Democracy. Cambridge, MA: Harvard University Press.

van der Meer, Tom. 2010. "In what we trust? A multi-level study into trust in parliament as an evaluation of state characteristics." International Review of Administrative Sciences 76(3): $517-536$.

Micheletti, Michele, Andreas Follesdal, and Dietlind Stolle. 2003. Politics, Products, and Markets: Exploring Political Consumerism Past and Present. New Brunswick, NJ; London: Transaction Publishers.

Milligan, Kevin, Enrico Moretti, and Philip Oreopoulos. 2004. "Does education improve citizenship? Evidence from the United States and the United Kingdom.” Journal of Public Economics 88(9-10): 1667-1695.

Milner, Henry. 2002. Civic Literacy: How Informed Citizens Make Democracy Work. Hanover: University Press of New England. 
Mishler, William, and Richard Rose. 1997. “Trust, distrust and skepticism: Popular evaluations of civil and political institutions in post-communist societies." Journal of Politics 59(2): 418-451.

—. 2001. "What Are the Origins of Political Trust? Testing Institutional and Cultural Theories in Post-communist Societies." Comparative Political Studies 34(1): 30-62.

. 2005. "What Are the Political Consequences of Trust?" Comparative Political Studies 38(9): $1050-1078$.

Nagler, Jonathan. 1991. "The Effect of Registration Laws and Education on U.S. Voter Turnout.” American Political Science Review 85(4): 1393-1405.

Newton, Kenneth. 1999. "Social and Political Trust in Established Democracies." In Critical Citizens: Global Support for Democratic Government, ed. Pippa Norris. Oxford; New York: Oxford University Press, 169-187.

Nie, Norman H., Jane Junn, and Kenneth Stehlik-Barry. 1996. Education and Democratic Citizenship in America. Chicago: University of Chicago Press.

Norris, Pippa, ed. 1999a. Critical Citizens: Global Support for Democratic Government. Oxford; New York: Oxford University Press.

. 1999b. "Introduction: The Growth of Critical Citizens?" In Critical Citizens: Global Support for Democratic Government, ed. Pippa Norris. Oxford; New York: Oxford University Press, 1-27.

OECD. 2010. Education at a Glance 2010: OECD Indicators. Paris: OECD.

Pattie, Charles J., Patrick Seyd, and Paul Whiteley. 2004. Citizenship in Britain: Values, Participation, and Democracy. Cambridge; New York: Cambridge University Press. 
Pharr, Susan J., and Robert D. Putnam, eds. 2000. Disaffected Democracies: What's Troubling the Trilateral Countries? Princeton, N.J.: Princeton University Press.

Powell, G. Bingham. 1986. “American Voter Turnout in Comparative Perspective.” American Political Science Review 80: 17-44.

Rohrschneider, Robert, and Rudiger Schmitt-Beck. 2002. “Trust in Democratic Institutions in Germany: Theory and Evidence Ten Years After Unification.” German Politics 11(3): 35-58.

Rothstein, Bo, and Eric M. Uslaner. 2005. “All for One: Equality, Corruption, and Social Trust.” World Politics 58(1): 41-72.

Scharpf, Fritz. 1999. Governing in Europe: Effective and Democratic? New York: Oxford University Press.

Seligson, Mitchell A. 2002. "The Impact of Corruption on Regime Legitimacy: A Comparative Study of Four Latin American Countries.” Journal of Politics 64(2): 408-433.

Seligson, Mitchell A., and Julio F. Carrión. 2002. "Political Support, Political Skepticism, and Political Stability in New Democracies." Comparative Political Studies 35(1): 58 -82.

Snijders, T.A.B., and Roel J. Bosker. 1999. Multilevel Analysis: An Introduction to Basic and Advanced Multilevel Modeling. London; New Delhi; Thousand Oaks, CA: Sage Publications.

Steenbergen, Marco R., and Bradford S. Jones. 2002. "Modeling Multilevel Data Structures.” American Journal of Political Science 46(1): 218-237.

Treisman, Daniel. 2000. “The Causes of Corruption: A Cross-National Study.” Journal of Public Economics 76(3): 399-457. 
Tyler, Tom R. 1990. Why People Obey the Law. New Haven: Yale University Press.

Verba, Sidney, Norman H. Nie, and Jae-On Kim. 1978. Participation and Political Equality: a Seven-Nation Comparison. Cambridge; New York: Cambridge University Press.

Verba, Sidney, Kay Lehman Schlozman, and Henry E. Brady. 1995. Voice and Equality: Civic Voluntarism in American Politics. Cambridge, Mass.: Harvard University Press.

Vogt, W.P. 1997. Tolerance and Education: Learning to Live with Diversity and Difference. London; New Delhi; Thousand Oaks, CA: Sage Publications.

Warren, Mark E. 2004. "What Does Corruption Mean in a Democracy?” American Journal of Political Science 48(2): 328-343.

Zmerli, Sonja, and Kenneth Newton. 2008. "Social Trust and Attitudes toward Democracy." Public Opinion Quarterly 72(4): 706-724. 
Table 1: Effects of education and corruption on institutional trust

\begin{tabular}{|c|c|c|}
\hline Independent variable & Estimate & (Std. Error) \\
\hline \multicolumn{3}{|l|}{ Main variables of interest } \\
\hline \multicolumn{3}{|l|}{ Education } \\
\hline \multicolumn{3}{|l|}{ (Reference: not completed and basic) } \\
\hline Lower secondary & $-0.100 * * *$ & $(0.172)$ \\
\hline Upper and post secondary & $-1.292 * * *$ & $(0.148)$ \\
\hline $\mathrm{BA}$ and higher & $-1.587 * * *$ & $(0.201)$ \\
\hline Corruption & 0.093 & $(0.060)$ \\
\hline Corruption $\times$ Lower secondary & $0.145 * * *$ & $(0.025)$ \\
\hline Corruption $\times$ Upper and post secondary & $0.189 * * *$ & $(0.022)$ \\
\hline Corruption $\times$ BA and higher & $0.242 * * *$ & $(0.029)$ \\
\hline \multicolumn{3}{|l|}{ Individual-level controls } \\
\hline Male & -0.021 & $(0.019)$ \\
\hline Age & $-0.029 * * *$ & $(0.003)$ \\
\hline $\mathrm{Age}^{2} / 1000$ & $0.267 * * *$ & $(0.030)$ \\
\hline Father's education & $0.022 *$ & $(0.008)$ \\
\hline Religious adherence & $0.170 * * *$ & $(0.023)$ \\
\hline Attendance of religious services & $0.063 * * *$ & $(0.008)$ \\
\hline Income & $0.022 * * *$ & $(0.004)$ \\
\hline \multicolumn{3}{|l|}{$\begin{array}{l}\text { Election winner-loser status } \\
\text { (Reference: winner) }\end{array}$} \\
\hline Loser & $-0.298 * * *$ & $(0.022)$ \\
\hline Nonvoter & $-0.463 * * *$ & $(0.026)$ \\
\hline Social trust & $0.184 * * *$ & $(0.004)$ \\
\hline Satisfaction with the economy & $0.290 * * *$ & $(0.005)$ \\
\hline \multicolumn{3}{|l|}{ Country-level controls } \\
\hline GDP per capita / 1000 & -0.017 & $(0.014)$ \\
\hline Unemployment & -0.048 & $(0.037)$ \\
\hline Central and Eastern Europe & $-0.533^{*}$ & $(0.225)$ \\
\hline Disproportionality of the electoral system & 0.009 & $(0.015)$ \\
\hline Intercept & $3.080 * * *$ & $(0.718)$ \\
\hline \multicolumn{3}{|l|}{ Random effects } \\
\hline Variance (Country) & $0.053 * *$ & \\
\hline Variance (BA and higher) & 0.023 & \\
\hline Variance (Upper and post secondary) & 0.005 & \\
\hline Variance (Lower secondary) & 0.009 & \\
\hline Variance (Individual) & $2.353 * * *$ & \\
\hline$N$ (Individuals) & 27,785 & \\
\hline$N$ (Countries) & 21 & \\
\hline$-2 \times$ Log Likelihood & 102737 & \\
\hline
\end{tabular}




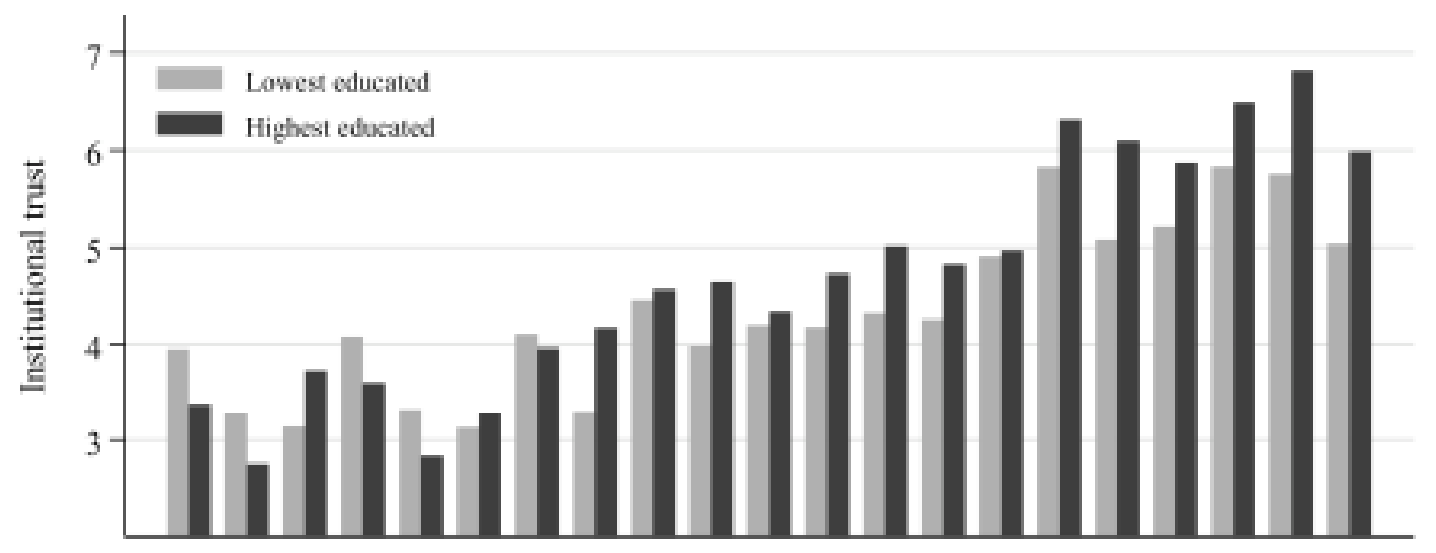

RO HR PL GR LV HU CZ PT ES EE SI FR BE GB DE NO NL CH FI DK SE

Countries sorted by Corruption Perception Index

Figure 1: Institutional trust across educational levels 


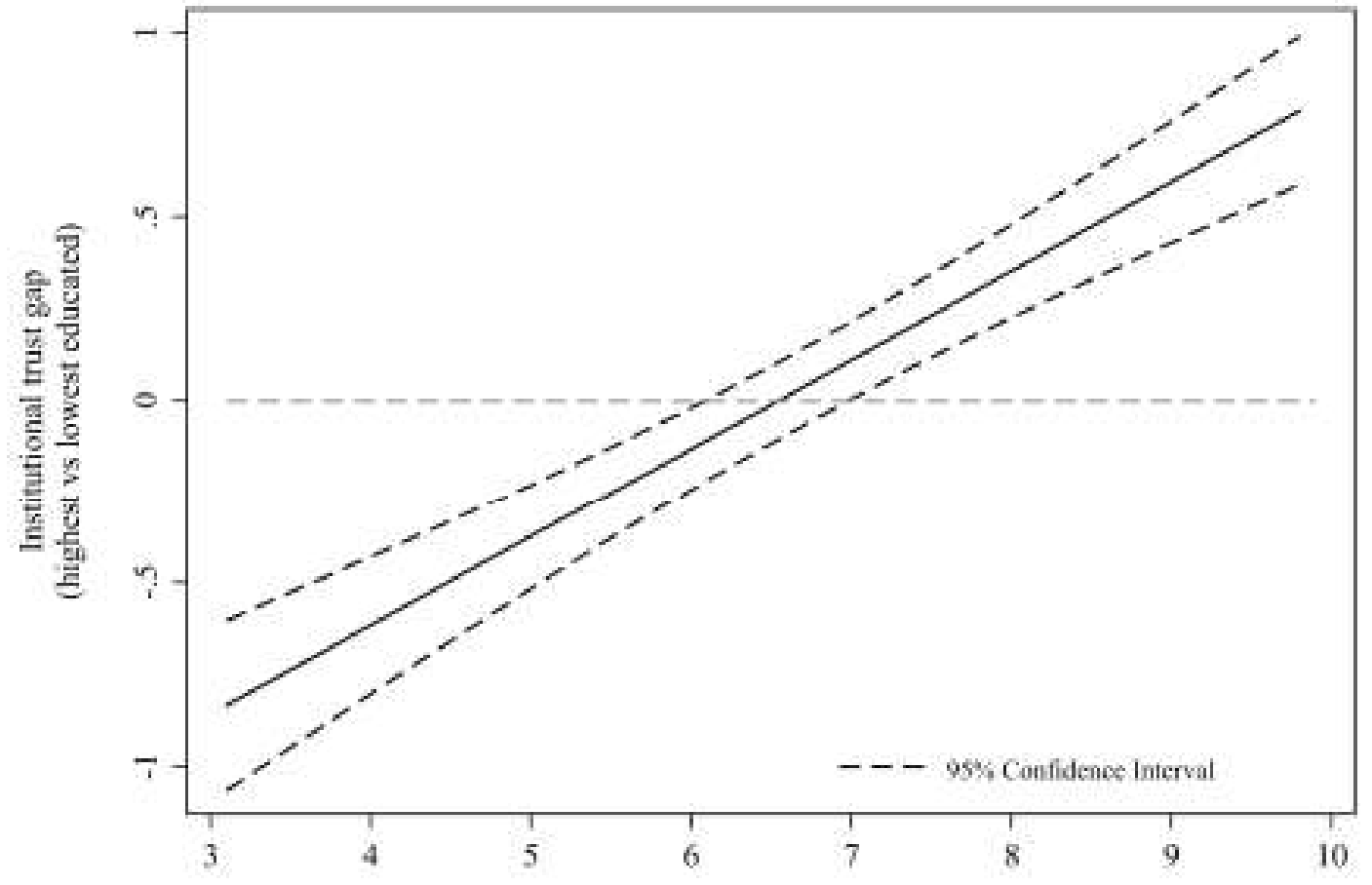

Corruption Perception Index

Figure 2: The difference in institutional trust between the highest and lowest educated across levels of corruption 


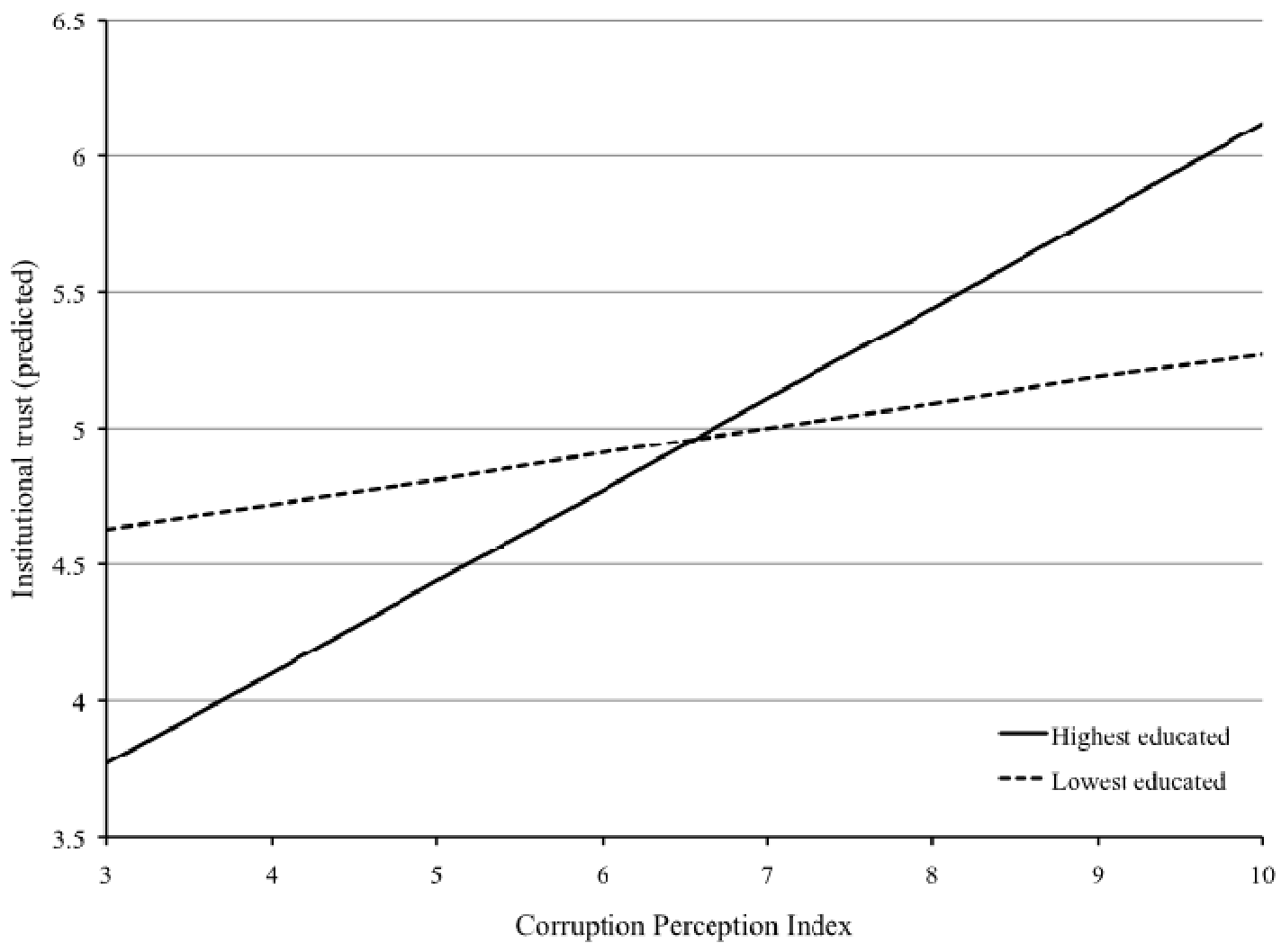

Figure 3: Predicted values of institutional trust across levels of corruption and education groups 